\title{
The Oxidative Status of Children with Acyanotic Congenital Heart Diseases: A Randomized Controlled Study
}

\author{
Asiyanotik Doğumsal Kalp Hastalığı olan Çocuklarda Oksidatif Durum: Randomize Kontrollü bir Çalışma
}

\author{
Ayhan Pektaş ${ }^{1}$, Bugra H. Koca ${ }^{2}$, Bilgehan M. Pektaş ${ }^{3}$, Resit Koken ${ }^{4}$
}

\footnotetext{
${ }^{1}$ Afyon Kocatepe University Hospital, Department of Pediatric Cardiology, Afyonkarahisar, Turkey

${ }^{2}$ Afyon Kocatepe University Medical Faculty, Department of Biochemistry, Afyonkarahisar, Turkey

${ }^{3}$ Afyon Kocatepe University Medical Faculty, Department of Pharmacology, Afyonkarahisar, Turkey

${ }^{4}$ Afyon Kocatepe University Hospital, Department of Pediatric Neurology, Afyonkarahisar, Turkey
}

\section{ABSTRACT}

Objective: This study aims to investigate the role of oxidative stress congenital heart defects with left-to-right shunt by determining total oxidant status (TOS), total antioxidant status and oxidative stress index (OSI) in affected children.

Methods: This is a prospective, randomized case-control study which reviews 40 healthy children and 40 children who have congenital heart defects with left-to-right shunt.

Results: The healthy children and the children who have congenital heart defects with left-to-right shunt are statistically similar with respect to age, sex, height, weight and body mass index ( $p>0.05$ for all). Both groups have statistically similar echocardiography findings including interventricular septum thickness, left ventricular internal diameter, left ventricular posterior wall, systolic volume, end diastolic volume, fractional shortening, ejection fraction and left ventricular mass values ( $p>0.05$ for each). These groups are also statistically similar in aspect of myocardial performance index, $E^{\prime}, A^{\prime}, S^{\prime}$, relaxation time and contraction time values that have been specified for left ventricle, interventricular septum and right ventricle ( $p>0.05$ for each). The healthy children and the children with congenital heart defects have statistically similar blood count parameters as well as serum concentrations of vitamin $\mathrm{D}$ and brain natriuretic peptide. The children who have congenital heart defects with left-to-right shunt have significantly higher TOS and OSI values than those of the healthy children (respectively, $35.6 \pm 2.8 \mathrm{nmol}$ $\mathrm{H}_{2} \mathrm{O}_{2}$ equiv/mg protein vs $16.1 \pm 4.6 \mathrm{nmol} \mathrm{H}_{2} \mathrm{O}_{2}$ equiv/mg protein, $\mathrm{p}=0.018$ and $32.4 \pm 1.4$ vs $11.5 \pm 3.2, \mathrm{p}=0.022$ ).

Conclusion: The imbalance between the prooxidant and antioxidant reactions causes an enhancement in oxidative stress which may contribute to the pathogenesis of congenital heart defects with left-to-right shunting.

Key Words: Congenital heart defects, left-to-right shunt, oxidative stress

\section{ÖZET}

Amaç: Bu çalışmada, soldan sağa şantlı doğumsal kalp hastalığı olan çocuklarda, total oksidan statü (TOS), total antioksidan statü (TAS) ve oksidatif stress indeksi (OSI) belirlenerek etkilenmiş çocukların oksidatif durumunun değerlendirilmesi amaçlanmaktadır.

Gereç ve Yöntem: Bu ileriye dönük, randomize, vaka-kontrol çalışmasında, 40 sağlıkı çocukla soldan sağa şantı doğumsal kalp hastalı̆ı bulunan 40 çocuk karşılaştırılmışıır.

Bulgular: Sağlıklı çocuklarla soldan sağa şantlı doğumsal kalp hastalığı bulunan çocuklar; istatistiksel olarak benzer yaşa, cinsiyete, vücut ağırlığına, boya ve vücut kitle indeksine sahiptir (hepsi için p>0.05). Bu iki grup, interventriküler septum kalınlığı, sol ventrikül iç çapı, sol ventrikül posterior duvar kalınlığı, sistolik hacim, diastol sonu hacim, fraksiyonel kısalma, ejeksiyon fraksiyonu ve sol ventrikül kitle değerleri gibi ekokardiyografi bulguları bakımından istatistiksel olarak benzerdir (her biri için $p>0.05$ ). Ayrıca, iki grup da, sol ventrikül, interventriküler septum ve sağ ventrikül için myokardial performans indeksi, $E^{\prime}, A^{\prime}, S^{\prime}$, gevşeme zamanı ve kontraksiyon zamanı değerleri açısından istatistiksel olarak benzerdir (hepsi için $\mathrm{p}>0.05$ ). sağlıklı çocuklarla soldan sağa şantlı doğumsal kalp hastalığı bulunan çocuklar; istatistiksel olarak benzer kan sayımı parametrelerine, serum D vitamini ve beyin natriüretik peptit konsantrasyonlarına sahiptir. Sağlıklı çocuklarla karşılaştıııldığında, soldan sağa şantlı doğumsal kalp hastalığı bulunan çocuklara ait TOS ve OSI değerleri anlamlı olarak yüksektir (sırasıyla, TOS için, $35.6 \pm 2.8 \mathrm{nmol} \mathrm{H}_{2} \mathrm{O}_{2}$ equiv/mg protein vs $16.1 \pm 4.6 \mathrm{nmol}$ $\mathrm{H}_{2} \mathrm{O}_{2}$ equiv/mg protein, $\mathrm{p}=0.018$ ve OSI için $32.4 \pm 1.4$ vs $11.5 \pm 3.2, \mathrm{p}=0.022$ ). Sonuç: Prooksidan ve antioksidan reaksiyonların arasındaki dengesizlik, oksidatif stres artışına yol açar ve bu artış, soldan sağa şantı doğumsal kalp hastalıklarının patogenezine katkıda bulunabilir.

Anahtar Sözcükler: Doğumsal kalp hastalıkları, soldan sağ şant, oksidatif stres Geliş Tarihi: 16.02.2016

Kabul Tarihi: 12.04 .2016 


\section{INTRODUCTION}

Congenital heart defect can be defined as a problem in the structure of the heart which is present at birth. Congenital heart defects are usually evaluated in two groups: cyanotic and acyanotic heart defects. In the case of non-cyanotic heart defects, blood flows from the left side of the heart to the right side of the heart due to a structural deformity. Individuals with left-toright shunting often retain normal levels of oxyhemoglobin saturation in systemic circulation. Common left-to-right shunt lesions include atrial septal defect (ASD), ventricular septal defect (VSD), patent ductus arteriosus (PDA), endocardial cushion defect (ECD) and partial anomalous pulmonary venous return (PAPVR). Left to right shunt causes an elevation of pulmonary blood flow, which triggers obstructive and obliterative alterations in the pulmonary vascular bed and a progressive increase in pulmonary vascular tone (1-4).

Oxidative stress occurs as a result of an imbalance between the oxidant status and the antioxidant defense mechanisms of a human body. It has been well established that oxidative stress induces apoptosis and the generation of reactive oxygen radicals which may be responsible for cellular damage (5-7).

Oxidative stress is a central mechanism of cellular damage that affects all organs and tissues. This imbalance between the oxidant status and antioxidant mechanisms is associated with several serious pediatric diseases such as bronchopulmonary dysplasia, respiratory distress syndrome, necrotizing enterocolitis, periventricular leukomalacia, hypoxic-ischemic encephalopathy and sudden infant death syndrome (8-10).

Since there are numerous oxidants and antioxidants in the body, measuring different oxidant and antioxidant molecules is impractical. That's why; measuring the total oxidant status (TOS) and total antioxidant status (TAS) is more valid and reliable (11). The present study aims to investigate the role of oxidative stress congenital heart defects with left-to-right shunt by determining TOS, TAS and oxidative stress index (OSI) in affected children.

\section{MATERIALS and METHODS}

The present study was approved by the Ethical Committee and Institutional Review Board of Afyon Kocatepe University Hospital, where it was conducted between January 2015 and January 2016. The parents of all participants gave written informed consent.

Patients

This is a cross-sectional, randomized case-control study which reviews 40 healthy children and 40 children who have congenital heart defects with left-to-right shunt. The healthy controls were randomly chosen from the children who were referred to the study center due to innocent murmurs during the study period. The pediatric patients with acyanotic congenital heart defects were also randomly chosen from the children who were diagnosed with left-to-right shunting during the study period. Randomization was performed by using sequentially numbered, sealed and opaque envelopes constructed from a random number table.

The children with any chronic disease, associated infections, elevated acute phase reactants, abnormal serum electrolytes, renal dysfunction and use of antioxidant medications were excluded. Data related with the age, gender, height and weight of the participants were recorded. Body mass index was calculated according to the following formula:

$$
\text { Body mass index }\left(\mathrm{kg} / \mathrm{m}^{2}\right)=\text { Body weight }(\mathrm{kg}) / \text { Body height }^{2}\left(\mathrm{~m}^{2}\right)
$$

\section{Echocardiography Examination}

Echocardiography examination was performed by using equipment with 3- and 5-MHz transducers (Vivid S6, GE Healthcare, UK) between 24-48 hours after the diagnosis of ARF, and before the anti-inflammatory treatment was initiated. A standardized cross-sectional and Doppler echocardiography examination was performed with multiple orthogonal parasternal, apical and subcostal views with the patient in the left lateral decubitus position.

\section{Laboratory Studies}

Complete blood count including hemoglobin, mean corpuscular volume (MCV), red cell distribution width (RDW), leukocyte count, neutrophil/lymphocyte ratio, platelet count, and mean platelet volume (MPV) was made by automated counter (Coulter analyzer, Max Instruments Laboratory, Milan, Italy). Serum concentrations of vitamin D were measured by radioimmunoassay (DSL Diagnostic Systems Laboratories, USA), whereas serum levels of brain natriuretic peptide (BNP) were measured by electrochemiluminescence immunoassay (Elecsys 2010 analyzer, Roche Diagnostics, Mannheim, Germany). The intra-assay and inter-assay coefficients of variation (CVs) for vitamin D were $1.3 \%$ and $1.8 \%$ respectively, while the intra-assay and inter-assay CVs for BNP were $1.8 \%$ and $1.5 \%$ respectively.
Oxidative stress in acyanotic congenital heart defects

The TOS of each supernatant fraction was determined using a novel automated measurement method that was also developed by Erel (12). The oxidants in the sample oxidize the ferrous ion-o-dianisidine complex to ferric ions. The oxidation reaction is enhanced by glycerol molecules in the reaction medium. The ferric ion makes a colored complex with xylenol orange in an acidic medium. The color intensity, which is measured spectrophotometrically, is related to the total amount of oxidant molecules present in the sample. The assay is calibrated with hydrogen peroxide, and the results are expressed in $\mathrm{nmol} \mathrm{H}_{2} \mathrm{O}_{2}$ equiv/mg protein.

The TAS of each supernatant fraction was determined using the novel automated measurement method developed by Erel (13). In this method, ferrous ion solution present in Reagent 1 is mixed with hydrogen peroxide, which is present in Reagent 2 . The sequentially produced radicals, including the brown-colored dianisidinyl radical cation produced by the hydroxyl radical, are also potent radicals. Using this method, the antioxidant effect in the sample against these potent-free radical reactions that are initiated by the produced hydroxyl radicals is measured. The results are expressed as nmol Trolox equiv/mg protein.

The OSI value was computed by the following formula (14):

OSI (arbitrary unit) = TOS (mmol H2O2 Eqv./L) / TAC (mmol Trolox Eqv./L)

\section{Statistical Analysis}

Collected data were analyzed by Statistical Package for Social Sciences version 18.0 (SPSS IBM Software, Armonk, NY, USA). Continuous variables were expressed as mean \pm standard deviation (range: minimum-maximum) and categorical variables were denoted as numbers or percentages. SmirnovKolmogorov test was used to test the variable distributions. Student $t$-test, chi-square test and Mann Whitney $U$ test were used for the comparisons. A post-hoc analysis was carried out to make a retrospective power analysis and a cohort size of 80 children ( 40 healthy children and 40 children who have congenital heart defects with left-to-right shunt) was found to have $64.6 \%$ power to detect a difference at the 0.05 significance level. Two-tailed $p$ values less than 0.05 were accepted to be statistically significant.

\section{RESULTS}

The children who had congenital heart defects with left-to-right shunting consisted of 27 children with VSD, 8 children with ASD and 5 children with PDA. Table 1 compares the demographic characteristics of the healthy children and children who have congenital heart defects with left-to-right shunt. Both groups are statistically similar with respect to age, gender, height, weight and body mass index ( $p>0.05$ for each). Fourteen children who had congenital heart defects with left-to-right shunt had Class I disease and the remaining 26 children had Class II disease, according to Ross classification. The mean systemic oxygen saturation of the children with leftto-right shunt was calculated to be $91.6 \pm 3.5 \mathrm{mmHg}$ (range: $88-96 \mathrm{mmHg}$ ).

Table 1: Demographic Characteristics of the Study Cohort

\begin{tabular}{lccc}
\hline & $\begin{array}{c}\text { Congenital heart } \\
\text { defects with left- } \\
\text { to-right shunt } \\
(\mathbf{n = 4 0 )}\end{array}$ & $\begin{array}{c}\text { Healthy } \\
\text { controls } \\
(\mathbf{n}=40)\end{array}$ & $\mathbf{p}$ \\
& $1.32 \pm 0.09$ & $1.36 \pm 0.40$ & 0.188 \\
\hline Age (years) & $20 / 20(50 \% / 50 \%)$ & $18 / 22$ & 0.190 \\
Male/Female & $0.66 \pm 0.01$ & $(45 \% 55 \%)$ & 0.176 \\
Height $(\mathrm{m})$ & $7.6 \pm 0.3$ & $0.62 \pm 0.01$ & 0.182 \\
Weight $(\mathrm{kg})$ & $17.3 \pm 0.6$ & $7.8 \pm 1.1$ & 0.154 \\
Body mass & & $20.3 \pm 1.7$ & \\
index $\left(\mathrm{kg} / \mathrm{m}^{2}\right)$ & & & \\
\hline
\end{tabular}

Table 2 demonstrates the echocardiography findings of the healthy children and the children with left-to-right shunting. Both groups have statistically similar fractional shortening, ejection fraction, systolic and end diastolic volumes, interventricular septum thickness, and left ventricle internal diameter, posterior wall thickness and mass values ( $p>0.05$ for all). 
Table 2: Echocardiography Findings of the Study Cohort

\begin{tabular}{|c|c|c|c|}
\hline & $\begin{array}{c}\text { Congenital } \\
\text { heart } \\
\text { defects } \\
\text { with left- } \\
\text { to-right } \\
\text { shunt } \\
(n=40)\end{array}$ & $\begin{array}{c}\text { Healthy } \\
\text { controls } \\
(n=40)\end{array}$ & p \\
\hline Interventricular septum end systole $(\mathrm{cm})$ & $0.89 \pm 0.07$ & $0.99 \pm 0.08$ & 0.192 \\
\hline Interventricular septum end diastole $(\mathrm{cm})$ & $0.66 \pm 0.02$ & $0.72 \pm 0.03$ & 0.164 \\
\hline Left ventricular internal diameter end systole $(\mathrm{cm})$ & $1.20 \pm 0.06$ & $1.68 \pm 0.07$ & 0.346 \\
\hline \multirow{2}{*}{$\begin{array}{l}\text { Left ventricular internal diameter end diastole } \\
(\mathrm{cm})\end{array}$} & $2.22 \pm 0.07$ & $2.72 \pm 0.11$ & 0.278 \\
\hline & $0.89 \pm 0.03$ & $1.11 \pm 0.05$ & 0.355 \\
\hline Left ventricular posterior wall end systole $(\mathrm{mm})$ & $0.63 \pm 0.03$ & $0.76 \pm 0.05$ & 0.314 \\
\hline Left ventricular posterior wall end diastole $(\mathrm{mm})$ & $23.5 \pm 1.1$ & $25.7 \pm 1.9$ & 0.177 \\
\hline Systolic volume (ml) & $36.3 \pm 1.3$ & $33.4 \pm 2.7$ & 0.136 \\
\hline End diastolic volume (ml) & $45.5 \pm 1.2$ & $39.9 \pm 1.4$ & 0.288 \\
\hline Fractional shortening (\%) & $77.0 \pm 1.6$ & $71.6 \pm .8$ & 0.169 \\
\hline Ejection fraction (\%) & $25.4 \pm 2.7$ & $29.0 \pm 6$ & 0.274 \\
\hline Left ventricular mass & $59.8 \pm 7.6$ & $63.6 \pm 5.2$ & 0.326 \\
\hline Left ventricular mass index & $0.75 \pm 0.05$ & $0.72 \pm 0.02$ & 0.205 \\
\hline Aorta/Left atrium & $1.92 \pm 0.06$ & $2.50 \pm 0.11$ & 0.222 \\
\hline Tricuspid annular plane systolic excursion & $1.50 \pm 0.05$ & $2.13 \pm 0.12$ & 0.249 \\
\hline Mitral annular plane systolic excursion & & & \\
\hline
\end{tabular}

Table 3 presents the tissue Doppler echocardiography findings of the healthy children and the children who have congenital heart defects with left-to-right shunt. Both groups are statistically similar in aspect of myocardial performance index, $E^{\prime}, A^{\prime}, S^{\prime}$, relaxation time and contraction time values that have been specified for left ventricle, interventricular septum and right ventricle ( $p>0.05$ for all).

Table 3: Tissue Doppler Echocardiography Findings of the Study Population

\begin{tabular}{|c|c|c|c|}
\hline & $\begin{array}{l}\text { Congenital } \\
\text { heart defects } \\
\text { with left-to- } \\
\text { right shunt } \\
(n=40)\end{array}$ & $\begin{array}{l}\text { Healthy } \\
\text { controls } \\
(n=40)\end{array}$ & p \\
\hline Left ventricular myocardial performance & $56.9 \pm 2.3$ & $54.1 \pm 2.2$ & 0.148 \\
\hline index & $0.104 \pm 0.004$ & $0.133 \pm 0.007$ & 0.316 \\
\hline Left ventricle $E^{\prime}$ & $0.067 \pm 0.004$ & $0.071 \pm 0.004$ & 0.119 \\
\hline Left ventricle $A^{\prime}$ & $1.69 \pm 0.11$ & $1.94 \pm 0.12$ & 0.119 \\
\hline Left ventricle $E^{\prime} / A^{\prime}$ & $0.074 \pm 0.003$ & $0.114 \pm 0.002$ & 0.244 \\
\hline Left ventricle $S^{\prime}$ & $46.2 \pm 1.9$ & $50.3 \pm 1.8$ & 0.056 \\
\hline Left ventricle relaxation time & $49.7 \pm 1.7$ & $54.4 \pm 1.9$ & 0.124 \\
\hline Left ventricle contraction time & $1.44 \pm 0.07$ & $1.39 \pm .13$ & 0.119 \\
\hline Left ventricle ME/MA & $58.4 \pm 2.5$ & $50.0 \pm 2.2$ & 0.216 \\
\hline Interventricular septum & $0.093 \pm 0.003$ & $0.093 \pm 0.004$ & 0.220 \\
\hline performance index & $0.069 \pm 0.004$ & $0.064 \pm 0.003$ & 0.199 \\
\hline Interventricular septum $\mathrm{E}^{\prime}$ & $0.061 \pm 0.003$ & $0.055 \pm 0.002$ & $\begin{array}{l}0.199 \\
0.165\end{array}$ \\
\hline Interventricular septum A' & $46.2 \pm 1.9$ & $45.4 \pm 2.2$ & 0.174 \\
\hline Interventricular septum $\mathrm{S}^{\prime}$ & $53.1 \pm 1.5$ & $49.5 \pm 1.7$ & $\begin{array}{l}0.1 / 4 \\
0.188\end{array}$ \\
\hline Interventricular septum relaxation time & $53.3 \pm 2.9$ & $52.5 \pm 1.9$ & 0.188 \\
\hline Interventricular septum contraction time & $0.147 \pm 0.008$ & $0.126 \pm 0.006$ & 0.159 \\
\hline Right ventricle myocardial performance index & $0.107 \pm 0.006$ & $0.122 \pm 0.006$ & 0.177 \\
\hline Right ventricle $\mathrm{E}^{\prime}$ & $1.54 \pm 0.13$ & $1.29 \pm 0.1$ & 0.236 \\
\hline Right ventricle $A^{\prime}$ & $0.114 \pm 0.004$ & $0.134 \pm 0.018$ & 0.288 \\
\hline Right ventricle $E^{\prime} / A^{\prime}$ & $43.7 \pm 1.8$ & $52.4 \pm 2.3$ & 0.288 \\
\hline Right ventricle $S^{\prime}$ & $52.1 \pm 1.7$ & $53.8 \pm 2.0$ & 0.328 \\
\hline Right ventricle relaxation time & $14.8 \pm 1.5$ & $11.8 \pm 1.4$ & 0.376 \\
\hline Right ventricle contraction time & & & 0.288 \\
\hline \multirow[t]{2}{*}{ Right ventricle TE/TA } & & & 0.269 \\
\hline & & & 0.414 \\
\hline
\end{tabular}

Table 4 displays the biochemical characteristics of the healthy children and the children who have congenital heart defects with left-to-right shunt. Both groups have statistically similar serum levels of vitamin D and BNP as well as blood count parameters including hemoglobin, MCV, RDW, leukocyte count, neutrophil/lymphocyte ratio, MPV, platelet count, platelet-tolymphocyte ratio ( $p>0.05$ for each).
Table 4: Biochemical Characteristics of the Study Cohort

\begin{tabular}{lccc} 
Table 4: Biochemical Characteristics of the Study Cohort & $\begin{array}{c}\text { Congenital heart } \\
\text { defects with left-to- } \\
\text { right shunt }(\mathbf{n}=\mathbf{4 0})\end{array}$ & $\begin{array}{c}\text { Healthy } \\
\text { controls } \\
(\mathbf{n}=\mathbf{4 0})\end{array}$ & $\mathbf{p}$ \\
\hline Hemoglobin (g/dl) & $11.6 \pm 0.2$ & $11.6 \pm 0.3$ & 0.199 \\
Mean corpuscular volume (fl) & $77.7 \pm 1.2$ & $78.1 \pm 1.7$ & 0.183 \\
Red cell distribution width (\%) & $16.2 \pm 0.9$ & $14.7 \pm 0.3$ & 0.144 \\
Leukocyte count $\left(\times 10^{3} / \mathrm{mm}^{3}\right.$ ) & $11.4 \pm 0.5$ & $12.3 \pm 0.5$ & 0.125 \\
Neutrophil/Lymphocyte count & $0.68 \pm 0.01$ & $0.42 \pm 0.03$ & 0.216 \\
Platelet count $\left(\times 10^{3} / \mathrm{mm}^{3}\right.$ ) & $413.7 \pm 19.6$ & $456.2 \pm 17.1$ & 0.266 \\
Platelet/Lymphocyte count & $53.4 \pm 11.2$ & $57.7 \pm 16.5$ & 0.284 \\
Mean platelet volume (fl) & $7.3 \pm 1.4$ & $7.7 \pm 0.1$ & 0.194 \\
Vitamin D (ng/ml) & $29.6 \pm 3.1$ & $29.4 \pm 2.6$ & 0.113 \\
Brain natriuretic peptide (pg/ml) & $57.9 \pm 3.6$ & $65.6 \pm 3.4$ & 0.236 \\
Total oxidant status (nmol & $35.6 \pm 2.8$ & $16.1 \pm 4.6$ & $0.018^{*}$ \\
$\mathrm{H}_{2} \mathrm{O}_{2}$ equiv/mg protein) & $1.1 \pm 0.2$ & $1.4 \pm 0.3$ & 0.137 \\
Total antioxidant status (nmol & $32.4 \pm 1.4$ & $11.5 \pm 3.2$ & $0.022^{*}$ \\
Trolox equiv/mg protein) & & & \\
Oxidative stress index & & & \\
\hline${ }^{*} \mathrm{p}<0.05$ was accepted to be statistically significant. & &
\end{tabular}

The children who have congenital heart defects with left-to-right shunt have significantly higher TOS and OSI values than those of the healthy children (respectively, $35.6 \pm 2.8 \mathrm{nmol} \mathrm{H}_{2} \mathrm{O}_{2}$ equiv/mg protein vs $16.1 \pm 4.6$ $\mathrm{nmol} \mathrm{H}_{2} \mathrm{O}_{2}$ equiv/mg protein, $\mathrm{p}=0.018$ and $32.4 \pm 1.4$ vs $11.5 \pm 3.2, \mathrm{p}=0.022$ ). However, both the healthy children and the children with congenital heart defects had statistically similar TAS values.

\section{DISCUSSION}

The pathogenesis of congenital heart defects is complex and involves genetic, inflammatory and autoimmune mechanisms. In patients with uncorrected left-to-right shunts, increased pulmonary pressure leads to vascular remodeling and endothelial dysfunction, secondary to an imbalance in vasoactive mediators which promotes vasoconstriction, inflammation, thrombosis, cell proliferation, impaired apoptosis and fibrosis (15). Aburawi et al. determined that inflammation decreases coronary flow in children with acyanotic heart defects (16).

The altered hemodynamic state of the children who have congenital heart defects with left-to-right shunt has been investigated by developing a lamb model with an in utero placement of an aorto-pulmonary vascular graft. Therefore, early disruption in reduction-oxidation balance and appearance of oxidative stress within pulmonary vasculature has been considered to be essential for the occurrence of endothelial dysfunction and vascular remodeling (17).

Previously published studies have focused on the use for the management of pulmonary hypertension, which is a late term complication of congenital heart defects with left-to-right shunts. The results of these clinical trials are not very promising, but a thorough identification of the temporal regulation of reactive oxygen species participating in the pathogenesis of congenital heart defects may help to achieve better clinical outcomes (18).

Karatas et al. assessed 25 children with rheumatic heart valve diseases, 25 children with congenital heart valve diseases and 20 healthy age-matched control subjects. The levels of plasma TAS, TOS and OSI values were found to be statistically similar in all groups. In addition, there were no correlations between the TOS and OSI values in the study cohort. Hence, it was declared that oxidative stress had no pronounced effect on the etiopathogenesis of congenital heart valve disorders during childhood (19).

Rokicki et al. evaluated the oxidant and antioxidant status in 23 infants suffering from congenital heart diseases (14 with left-to-right shunt and 9 with cyanotic heart defects) and 18 healthy infants. The study was based on the measurement of the activities of antioxidant enzymes (superoxide dismutase, catalase and glutathione peroxidase) in blood, the levels of low molecular weight antioxidants (vitamin E, uric acid and selenium) and the concentration of malondialdehyde as a marker of lipid peroxidation. These three groups had statistically similar activities of superoxide dismutase and catalase. When compared to the healthy controls, infants with acyanotic congenital heart diseases had significantly lower plasma vitamin E levels. The activity of glutathione peroxidase was significantly lower and the levels of oxidant molecules (malondialdehyde and uric acid) were significantly higher in infants with cyanotic heart defects than in the healthy controls (20). 
Ercan et al. conducted a case-controlled, cross-sectional study on 32 healthy children, 30 children with acyanotic heart disease and 29 children with cyanotic heart disease. They reported that the plasma TAS, TOS and OSI were significantly higher in children with cyanotic heart diseases than in children with acyanotic heart diseases and healthy controls. However, they were unable to detect significant differences between the TAS, TOS and OSI values of the healthy controls and children with acyanotic heart diseases (21).

Vitamin $D$ can be considered as a casual antioxidant which scavenges reactive oxygen species in the first stage before activation of other stresssensitive response pathways. It has been also shown that vitamin D levels are directly associated with anti-oxidant glutathione reductase and inversely associated with oxidant status markers such as superoxide dismutase and glutathione peroxidase in both healthy and diabetic adults $(22,23)$. However, this study failed to find a significant difference in vitamin D concentrations of the healthy children and the children who have congenital heart defects with left-to-right shunt.

To the best of our knowledge, this is the first randomized controlled study which aims to define the oxidant and antioxidant status of the children who have congenital heart diseases with left-to-right shunting. The present study compares 40 children with acyanotic heart defects and 40 healthy children who are matched with respect to age, gender and body mass index. Although a significant increase was specified in the TOS and OSI values of the children with acyanotic congenital heart diseases, no significant alteration can be indicated in their plasma TAS levels and serum vitamin D concentrations. This failure can be explained by the violation of the equilibrium between the oxidant and anti-oxidant mechanisms.

It has been demonstrated that oxidative stress plays a significant role in the pathogenesis of inflammatory disorders. An increase in oxidative stress induces apoptotic cell death and exerts negative effects on the immune system functions (24). The mechanism by which oxidative stress induces inflammation and vice versa is unclear but is of great importance, being apparently linked to many chronic inflammatory diseases (25). It has been also shown that ozone produces an initial direct injury to cell membranes, which may result in increased oxidative stress, which possibly affects macrophages and results in increased release of chemotactic stimuli for neutrophils. The consequent secondary inflammatory response may result in further cell injury and increased permeability (26). A complete blood count consists of inflammatory markers which include MCV, RDW, and MPV, leukocyte count, neutrophil/lymphocyte ratio and platelet/lymphocyte ratio $(27,28)$. That's why; this study has evaluated the healthy children and the children with congenital left-to-right shunting in aspect of these inflammatory markers and no significant difference could be detected. Such discrepancy may be attributed to the relatively small cohort size and mild-tomoderate progression of the congenital defect-related heart failure.

The findings of this randomized controlled study imply that the imbalance between the prooxidant and antioxidant reactions causes an enhancement in oxidative stress which contributes to the pathogenesis of congenital heart defects with left-to-right shunting. However, these findings should be interpreted carefully as there are several factors that limit their power. These factors include the relatively small cohort size, absence of children with cyanotic congenital heart disease and lack of longitudinal data.

Further research is warranted to clarify the role of oxidative stress in congenital heart defects with left-to-right shunts that affect children.

\section{Conflict of interest}

No conflict of interest was declared by the authors

\section{REFERENCES}

1. Bertoletti J, Marx GC, Hattge SP, Pellanda LC. Health-related quality of life in adolescents with congenital heart disease. Cardiol Young 2015; 25: 526-32.

2. Majnemer A, Limperopoulos C, Shevell MI, Rohlicek C, Rosenblatt B, Tchervenkov C. A new look at outcomes of infants with congenital heart disease. Pediatr Neurol 2009; 40: 197-204.

3. Rao PS. Consensus on timing of intervention for common congenital heart diseases: part I acyanoticheart defects. Indian J Pediatr 2013; 80: 32-8.

4. Favilli S, Santoro G, Ballo P, Arcangeli C, Bovenzi FM, Chiappa E, Conti U, Monopoli A, Murzi B, Rosini C, Zuppiroli A. Prevalence and clinical characteristics of adult patients with congenital heart disease in Tuscany. J Cardiovasc Med (Hagerstown) 2012; 13: 805-9.

5. Gutterman DD, Chabowski DS, Kadlec AO, Durand MJ, Freed JK, Ait-Aissa K, Beyer AM. The human microcirculation: Regulation of flow and beyond. Circ Res 2016; 118: 157-72.
6. Kvietys PR, Granger DN. Role of reactive oxygen and nitrogen species in the vascular responses to inflammation. Free Radic Biol Med 2012; 52: 556-92.

7. Piedrafita G, Keller MA, Ralser M. The impact of non-enzymatic reactions and enzyme promiscuity on cellular metabolism during (oxidative) stress conditions. Biomolecules 2015; 5: 2101-22.

8. Vakilian K, Ranjbar A, Zarganjfard A, Mortazavi M, Vosough-Ghanbari $\mathrm{S}$, Mashaiee $\mathrm{S}$, Abdollahi $\mathrm{M}$. On the relation of oxidative stress in delivery mode in pregnant women; a toxicological concern. Toxicol Mech Methods 2009; 19: 94-9.

9. Lurie S, Matas Z, Boaz M, Fux A, Golan A, Sadan O. Different degrees of fetal oxidative stress in elective and emergent cesarean section. Neonatology 2007; 92: 111-5.

10. Husain K, Hernandez W, Ansari RA, Ferder L. Inflammation, oxidative stress and renin angiotensin system in atherosclerosis. World J Biol Chem 2015; 6: 209-17.

11. Czerska M, Mikołajewska K, Zieliński M, Gromadzińska J, Wąsowicz W. Today's oxidative stress markers. Med Pr2015; 66: 393-405.

12. Erel $O$. A novel automated method to measure total antioxidant response against potent free radical reactions. Clin Biochem 2004; 37: 112-9.

13. Erel O. A new automated colorimetric method for measuring total oxidant status. Clin Biochem 2005; 38:1103-11.

14. Harma MI, Harma $\mathrm{M}$, Erel $\mathrm{O}$. Measuring plasma oxidative stress biomarkers in sport medicine. Eur J Appl Physiol 2006; 97: 505-8.

15. Calderón-Colmenero J, Sandoval Zárate J, Beltrán Gámez M. Pulmonary hypertension associated with congenital heart disease and Eisenmenger syndrome. Arch Cardiol Mex 2015; 85:32-49.

16. Aburawi $\mathrm{EH}$, Pesonen E. Pathophysiology of coronary blood flow in congenital heart disease. Int J Cardiol 2011; 151: 273-7.

17. Aggarwal S, Gross C, Fineman JR, Black SM. Oxidative stres and the development of endothelial dysfunction in congenital heart disease with increased pulmonary blood flow: lessons from the neonatal lamb. Trends Cardiovasc Med 2010; 20: 238-46.

18. Opotowsky AR. Clinical evaluation and management of pulmonary hypertension in the adult with congenital heart disease. Circulation 2015; 131: 200-10.

19. Karatas Z, Baysal T, Sap F, Altin H, Cicekler H. The role of tenascin- $\mathrm{C}$ and oxidative stress in rheumatic and congenital heart valve diseases: an observational study. Anadolu Kardiyol Derg 2013; 13: 350-6.

20. Rokicki W, Strzałkowski A, Kłapcińska B, Danch A, Sobczak A. Antioxidant status in newborns and infants suffering from congenital heart defects. Wiad Lek 2003; 56: 337-40.

21. Ercan S, Cakmak A, Kösecik M, Erel O. The oxidative state of children with cyanotic and acyanotic congenital heart disease. Anadolu Kardiyol Derg 2009; 9: 486-90.

22. Ceriello A. New insights on oxidative stress and diabetic complications may lead to a "causal" antioxidant therapy. Diabetes Care 2003; 26: 1589-96.

23. Saedisomeolia A, Taheri E, Djalali M, Djazayeri A, Qorbani M, Rajab A, Larijani B. Vitamin D status and its association with antioxidant profiles in diabetic patients. A cross-sectional study in Iran. Indian J Med 2013; 67: 29-37.

24. Chiavaroli V, Giannini C, De Marco S, Chiarelli F, Mohn A. Unbalanced oxidant-antioxidant status and its effects in pediatric diseases. Redox Rep 2011; 16: 101-7.

25. Salzano $S$, Checconi $P$, Hanschmann EM, Liilig $C H$, Bowler LD, Chan $P$, Vaudry D, Mengozzi M, Coppo L, Sacre S, Atkuri KR, Sahaf B, Herzenberg LA, Mullen L, Ghezzi P. Linkage of inflammation and oxidative stres via release of glutathionylated peroxiredoxin-2, which acts as a danger signal. Proc Natl Acad Sci USA 2014; 111: 12157-62.

26. Morrison D, Rahman I, MacNee W. Permeability, inflammation and oxidant status in airspace epithelium exposed to ozone. Respir Med 2006; 100: 2227-34.

27. Aktas G, Alcelik A,Kin Tekce B, Tekelioglu V, Sit M, Savli H. Red cell distribution width and mean platelet volume in patients with irritable bowel syndrome. Prz Gastroenterol 2014; 9: 160-3.

28. Ahbap E, Sakaci T, Kara E, Sahutoglu T, Koc Y, Basturk T, Sevinc M, Akgol C, Kayalar AO, Ucar ZA, Bayraktar F, Unsal A. Neutrophil-to-lymphocyte ratio and platelet-to-lymphocyte ratio in evaluation of inflammation in end-stage renal disease. Clin Nephrol 2015 Nov 2 (Epub ahead of print). 